\title{
Building Integrated Photovoltaic Systems for Single Family Dwellings: Innovation Concepts
}

\author{
Ali M. Memari1, Lisa D. Iulo², Ryan L. Solnosky³, Christopher R. Stultz ${ }^{3}$ \\ ${ }^{1}$ Department of Architectural Engineering and Department of Civil and Environmental Engineering, The \\ Pennsylvania State University, University Park, USA \\ ${ }^{2}$ Department of Architecture, The Pennsylvania State University, University Park, USA \\ ${ }^{3}$ Department of Architectural Engineering, The Pennsylvania State University, University Park, USA \\ Email: memari@engr.psu.edu, idl1@psu.edu, rls5008@engr.psu.edu, crs5011@psu.edu
}

Received 11 April 2014; revised 11 May 2014; accepted 18 May 2014

Copyright (C) 2014 by authors and Scientific Research Publishing Inc.

This work is licensed under the Creative Commons Attribution International License (CC BY). http://creativecommons.org/licenses/by/4.0/ c) (i) Open Access

\begin{abstract}
Growing consumer interest in distributed Building Integrated Photovoltaic (BIPV) Systems and industry competition to reduce installation costs are stimulating the development of deploying these materials to the residential sector of the building industry. This emerging market continues to attract the attention of many stakeholders, yet cohesive opportunities to deploy in residential sectors, specifically detached single-family dwellings, is scattered. As a result, this study of literature and implementation strategies through simple examples looks to identify several characteristics related to BIPV. Characteristics that were studied in this initial pilot study were design considerations for system selection, applicability to residential construction, and system and material options and enhancements. A case-study home was analyzed demonstrating opportunity for implementation of BIPV on an existing residence. Strategies for maximizing the energy-generating capacity of the system to achieve net-zero energy performance, including all building surfaces and landscaping were also explored. This body of work provides a state-of-the-art review on common materials as well as the more customizable types.
\end{abstract}

\section{Keywords}

Photovoltaic, Energy Efficiency, Solar Power, Single-Family Dwellings, Building Integrated Photovoltaic System

\section{Introduction}

Over 30 years of research has gone into efforts to accelerate the deployment of solar-electric systems by devel- 
oping photovoltaic (PV) products that are fully integrated with building materials [1]. The use of PV materials to produce energy is a well-studied and continues to be a heavily studied topic. Studies of established deployable technology going back to the mid-1990s are especially useful as a point-of-departure for this study [2]-[6]. Despite these efforts and high stakeholder interest in building-integrated PV (BIPV), the deployment of PV systems that are partially or fully integrated with building materials is low compared with rack-mounted PV systems, accounting for about $1 \%$ of the installed capacity of distributed PV systems worldwide [7] [8].

This technology is often used in new construction, especially commercial and institutional building applications, as an approach to net-zero energy or carbon-neutral design that are becoming popular [9]. Though popular and promising, the use of photovoltaic technology has often been limited by pre-established manufactured panels or assemblies with its application related to the constraints and conditions of a specific project, often attached to a roofing support structure with little integration into the actual facility it serves [10]. However, with proper implementation, photovoltaic materials can be integrated into many common building materials as BIPV to provide the added benefit of energy production while also serving as a functional component of the building assembly [8] [11] [12].

Even if BIPV opportunities are understood, there are many limitations ranging from cost to availability of materials presently known to be effective at a larger scale. Furthermore, usage of BIPV has been limited to small portions of the industry, primarily utilized in new construction and rarely in single-family residential projects. The exception is in specific show-case projects like those designed and constructed for the US Department of Energy's Solar Decathlon. This limits wider application since new construction only represents a small portion of the total available building stock where BIPV may be desirable. Further, these show-case applications are rarely affordable or easily transferable to market projects.

This work focuses on perhaps the largest market with potential in the industry, single-family residential environments. Single-family residential BIPV introduces an enormous market for solar energy production, but significant studies of specific PV technologies, products, PV integration, and application methods are necessary to allow for wider local adoption by residential building companies and homeowners [13]-[16]. Although some recent studies related to PV systems and PV electricity in the new home building market are available [16], there is little literature on PV and BIPV relevant to the existing single-family residential market; a market that far exceeds that of new construction and offers wide-ranging opportunity related to solar-electric power generation.

As the literature confirms (discussed in the next section), there is ample technology that supports a proof of concept to utilize BIPV in the residential market. However, it is clearly evident that the current target market is in new construction. New construction represents only a small portion of single-family residences, while all new construction residences eventually become existing buildings needing renovation down the lifecycle. Using this current model, it would take a considerable amount of time for market penetration. As a result, research into implementation on existing housing would allow for faster market penetration of BIPV and the ability for home owners to retrofit their homes for improved energy performance, especially when standard building components, such as shingles, siding, and windows, wear out or otherwise need replacement. This study presents ideas on possible implementation strategies of BIPV systems for existing buildings through a state-of-the-art review [17]. These concepts as well as techniques to improve the production of BIPV are discussed.

\section{Literature Background}

Today, BIPV products have more standardized designs that are intended to integrate with many common building materials with a large majority of them going for the residential market. Although the market prices for BIPV are still higher than for rack-mounted PV [1], new products offer lower costs and better performance than BIPV systems of the past. To understand BIPV applications and possibilities for untapped industry sectors, first an understanding as to what makes up a BIPV is needed. According to Strong [8] and Sinapis and Menno van den Donker [18], a BIPV system at the minimum includes:

- The PV modules that are either thin-film or crystalline, transparent, semi-transparent, or opaque;

- A charge controller to regulate the power into and out of the battery storage bank;

- A power storage system generally comprised of the utility grid in utility-interactive systems or a number of batteries in stand-alone systems;

- Power conversion equipment including an inverter to convert the PV modules' DC output to AC compatible with the utility grid; 
- Appropriate support and mounting hardware, wiring, and safety disconnects.

Applications for BIPVs in residential construction are currently generally limited to the roof surfaces where several companies have developed roofing shingles intended to look like traditional ceramic or asphalt shingles [19] [20]. Currently, Roof-mounted PV arrays (mostly made up of crystalline silicon cells/modules) are the predominant PV systems for homes that are to be equipped with solar energy generation technology [2] [4]. For buildings with limited roof areas but larger wall areas, facade surfaces of buildings, including non-south facing exposures, can significantly increase area for energy collection [11]. Other applications, although less specific, include the use of thin films and solar cells on glass window surfaces [21]. Occasionally, they are integrated into window overhangs and shading devices. BIPV systems seem to be the logical choice based on work by Perfetto [22] and Cole et al. [23]. Another reason for attractiveness of the BIPV system idea is that if the PV system becomes part of the envelope, the overall cost of material and installation may be reduced.

According to Eiffert and Kiss [9], most BIPV systems can be considered in one of two categories: façade systems (e.g., curtain walls, spandrel panels, and glazing) and roofing systems (e.g., shingles, tiles, standing seam products and skylights). Currently, BIPV developed building components include the following: rooftops, facades, atria/skylights, and shading elements based upon a search of manufacturers websites. According to Benemann et al. [12], facades can provide the following functions: façade and roof elements, daylighting, shading, noise reduction, and electricity generation. Furthermore, with additional use of other materials, attributes such as the following can also be added: fire-protection, insulation and sun protection. Perfetto [22] points out that the current trend is to prefabricate BIPV components with the same functions as the traditional components such that installation would not require highly trained labor.

Elzinga [16] suggests that if we qualify the construction industry as potentially innovative with respect to the deployment of BIPV technology, then the builders/organizations that participate in the residential building market may be considered to fit within the Rogers Adoptions/Innovator Curve, which looks like a normal distribution curve. This would then mean that $2.5 \%$ of the builders would be "innovators", $13.5 \%$ "early adopters", $34 \%$ "early majority”, 34\% "late majority”, and 16\% "laggards" [24]. Based on the definition of Koebel et al. [25], builders that can be considered as early adopters would include modular builders and multi-family builders, and single-family custom home builders. Those that could be considered innovative firms would have a technology advocate (a champion) within the firm, want to be creative and the first to use new products, or use technology transfer programs such as the Partnership for Advancing Technology in Housing (PATH), and universities. Furthermore, Elzinga [16] and Santos and Rüther [20] have identified that home purchasers often slow down use of new innovation in residential construction. Since they tend to be "risk adverse" and want the "tried and true" choices, then builders often follow the wishes of these home purchasers.

\section{Designing BIPV Systems}

When conducting the design of BIPV system, specialty considerations need to be addressed and accounted for. Due to BIPV being a less common system for residential homes, the process and considerations need to be explained in order to select the best options for the owner conditions. System designs are most influenced by PV performance considerations, and aesthetics are often secondary currently [1] [26]. The primary steps in designing a BIPV system according to Strong [8] and James et al. [1] are:

1) Before deciding upon design, first consider the application of energy-conscious design practices reduce the energy requirements;

2) Identify and select either a utility-interactive PV system or a stand-alone PV system;

3) Shift the peak building loads so that they match the peak power output of the PV array or, as appropriate, incorporate batteries into certain grid-tied systems to offset power demand periods;

4) Provide adequate ventilation so that power conversion efficiencies are not reduced due to elevated operating temperatures;

5) Evaluate using hybrid PV-solar thermal systems;

6) Identify if integrating day lighting and photovoltaic collection systems is reasonable;

7) Incorporate, if possible or viable, PV modules into shading devices;

8) Design the system for the local climate and environment;

9) Address site planning and orientation issues; 
10) Consider array orientation as different orientations can have a significant impact on the annual energy output;

11) Reduce building envelope and other on-site loads whenever possible.

Within this process, system selection characteristics need to be accounted for as they may strongly influence a system. Table 1 lists the eight consideration classes that vary from site and system performance to the design intent and maintenance. Strong [8] recommends that site planning and orientation (building and system) should be addressed early in the design. In particular, the array should be positioned to have the most sun exposure without being shaded by obstructions near or on the site (e.g., adjacent buildings, trees, etc.). It is also mentioned that surrounding surfaces that reflect light onto the array will be helpful to increase the efficiency of the system when possible to implement. Elzinga [16] further adds that it is essential to determine the orientation and slope of BIPV unit to minimize shading during the day and if shading is unavoidable, then efforts should be made to determine the significance of this shading and determine if reduced energy generation is acceptable, else effort should be made to perhaps remove the object.

NAHB [14] provided a comprehensive discussion on the development and installation of PV-metal roofing. According to the article, the design of integrated PV roofing was influenced by the type of PV module, nature of existing PV technology, existing battery technology, and characteristics of the charge controller and inverter. Expanding the results of a BIPV roof, the PV's supplied on average $30 \%$ of the house energy demand, while still providing $10 \%$ to the grid. The prevalent trend in the new construction market seems to be on roofing integration, whether in the form of shingle/metal panel replacement or by using applied panels. Use of these components is being extended to the façade systems. One of the advantages of these systems is the modular design that can easily be used to maximize available area for energy conversion and provide better inclination for solar efficiency. However, these products may be limited in current forms as they are designed primarily for use on the roof.

Issues that may evolve from BIPV design are not exclusively technical as the balance between design and construction issues can vary greatly according to the circumstances of each project (e.g., climate, client priorities, aesthetics) [7]. Nonetheless, with proper planning, the potential to utilize BIPV in building enclosures may be increased. Consideration into the local market also plays a large role in the utilization of BIPV. Even with industry-backed support, the payback period and system qualities are key to the acceptance of BIPV. As for payback, the accepted term for home owners is around 15 years, with the typical home owner willing to pay a $10 \%$ $15 \%$ premium for an alternative system that provides benefits. Most home owners do not look ahead of 15 years since they may relocate before that time and would not benefit from their decision to incorporate BIPV [16].

\section{Solar Energy Gain and Utilization Matrices for BIPV}

Based on the literature review and guidelines published on PV and BIPV, a matrix was developed to compare the attributes of three different BIPV systems (see Table 2). Table 2 was developed to be a starting point tool for a comparison of different BIPV systems that a designer may want to implement. The top category cells in row one are the attributes (nine total) for comparing the BIPV system. The matrix then is generated with as many alternatives as the designer wants to review (successive rules). The component area can be as general as a BIPV Exterior Wall System, more defined such as BIPV Integrated Vinyl Siding, or as specific as a product that is commercially available. Three sample specimens are shown in Table 2 to illustrate this tool. Attributes can be compared quantitatively for more effective comparisons. To use, each component type and attribute appropriate information is entered. Information for each system and attribute is generated or assumed (if information is not available) based on a question or series of questions relative to each category, the questions are listed in Table 3.

A second design tool matrix was developed to show attributes related to different aspects of selected systems and to assign trial scores to the systems for each attribute to provide a ranking system for multiple, acceptable systems (see Table 4). The ranking system is from 1 - 10 (with 1 being the lowest and 10 being the highest). Values associated with the scale in this chart are preliminary estimates, as further information and a better understanding of the attributes become known for a product or if the matrix is used on multiple projects, the scores and ranking should be refined as appropriate. Inclusion of a comments section to briefly describe the components can be used below the chart. The headings are described in the bulleted points and examples can be found in the Table 4. 
Table 1. BIPV system selection considerations (based on [7] [8]).

\begin{tabular}{|c|c|}
\hline Design Intent & Climatic \\
\hline $\begin{array}{l}\text { - } \text { Representation } \\
\text { - } \text { Aesthetics } \\
\text { - } \text { Economy } \\
\text { - } \text { Engineering } \\
\text { Product Development }\end{array}$ & $\begin{array}{l}\text { - Locations and their Climates } \\
\text { - } \text { Insulation } \\
\text { - Water } \\
\text { - Wind/Snow/Seismic Loads } \\
\text { Lightning }\end{array}$ \\
\hline Site & Environmental \\
\hline $\begin{array}{ll}\text { - } & \text { Real Estate } \\
\text { - } & \text { High-Rise vs. Low-Rise } \\
& \text { Litigation }\end{array}$ & $\begin{array}{l}\text { - Disposal of broken or replaced panels } \\
\text { - Hazardous, toxic and non-renewable materials } \\
\text { used in panel production } \\
\text { - Energy consumed in panel manufacturing } \\
\text { (embodied energy) }\end{array}$ \\
\hline Construction & Safety \\
\hline $\begin{array}{ll}\text { - } & \text { Installation } \\
\text { - } & \text { Dimensions } \\
\text { - } & \text { Details }\end{array}$ & $\begin{array}{l}\text { - Thermal stress } \\
\text { - Code requirements for tempered and/or laminated glass }\end{array}$ \\
\hline Maintenance & Mechanical/Electrical \\
\hline $\begin{array}{ll}\text { - } & \text { Cleaning } \\
\text { - } & \text { Maintenance }\end{array}$ & $\begin{array}{l}\text { - Ventilation of the Envelope } \\
\text { - Electrical Issues }\end{array}$ \\
\hline
\end{tabular}

Table 2. BIPV product comparison matrix with examples.

\begin{tabular}{|c|c|c|c|c|c|c|c|c|c|}
\hline 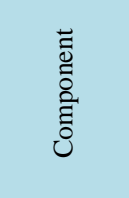 & 方葛 & 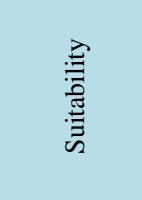 & $\underbrace{己}_{\text {:工工二 }}$ & 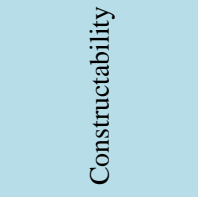 & 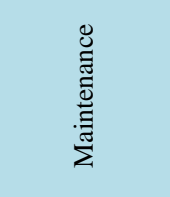 & 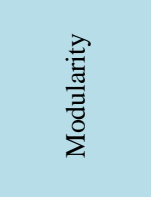 & 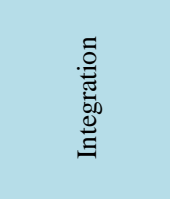 & 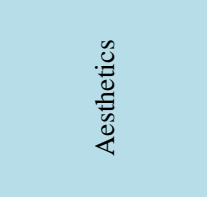 & 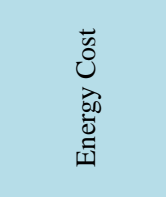 \\
\hline $\begin{array}{l}\text { Thin } \\
\text { Film }\end{array}$ & $\begin{array}{c}\text { Contained } \\
\text { within } \\
\text { widows }\end{array}$ & $\begin{array}{l}\text { Highly: } \\
\text { can be } \\
\text { semi-transp } \\
\text { arent/ } \\
\text { transparent } \\
\text { to allow } \\
\text { light } \\
\text { infiltration }\end{array}$ & $5-8 \%$ & $\begin{array}{c}\text { Requires } \\
\text { pre- } \\
\text { manufacturing, } \\
\text { may } \\
\text { incur long } \\
\text { lead } \\
\text { times for } \\
\text { material }\end{array}$ & $\begin{array}{c}\text { Requires } \\
\text { no special } \\
\text { maintenance, } \\
\text { may be } \\
\text { difficult to } \\
\text { replace }\end{array}$ & $\begin{array}{l}\text { Can be } \\
\text { applied to } \\
\text { differing } \\
\text { sizes, no } \\
\text { modularity } \\
\text { required }\end{array}$ & $\begin{array}{c}\text { “Plug and } \\
\text { Play” } \\
\text { capabilities, } \\
\text { Replaces } \\
\text { standard } \\
\text { windows }\end{array}$ & $\begin{array}{c}\text { Visually } \\
\text { acceptable } \\
\text { in certain } \\
\text { applications, } \\
\text { variety of } \\
\text { color, system } \\
\text { life is equal } \\
\text { to/greater } \\
\text { than } \\
\text { component life }\end{array}$ & $\begin{array}{c}\text { High energy } \\
\text { cost, use on } \\
\text { multiple } \\
\text { windows } \\
\text { creates } \\
\text { better } \\
\text { payback }\end{array}$ \\
\hline $\begin{array}{c}\text { Wall } \\
\text { Panel }\end{array}$ & $\begin{array}{c}\text { Exterior } \\
\text { crystalline } \\
\text { cells } \\
\text { within } \\
\text { wall panel }\end{array}$ & $\begin{array}{c}\text { Moderate: } \\
\text { replaces } \\
\text { façade } \\
\text { well, } \\
\text { limited } \\
\text { solar } \\
\text { availability }\end{array}$ & $12-15 \%$ & $\begin{array}{c}\text { Component } \\
\text { pre-manufacture } \\
\text { d. Heavy, } \\
\text { requires } \\
\text { replacement } \\
\text { of wall, addi- } \\
\text { tional } \\
\text { framing may } \\
\text { be required }\end{array}$ & $\begin{array}{l}\text { No special } \\
\text { maintenance, } \\
\text { difficult to } \\
\text { replace, } \\
\text { requires } \\
\text { removal of } \\
\text { weather } \\
\text { barrier } \\
\text { system }\end{array}$ & $\begin{array}{c}\text { Requires } \\
\text { modularity. } \\
\text { May not be } \\
\text { able to } \\
\text { use on } \\
\text { buildings } \\
\text { with odd } \\
\text { multiple } \\
\text { lengths }\end{array}$ & $\begin{array}{l}\text { “Plug and } \\
\text { Play”, } \\
\text { replaces } \\
\text { entire } \\
\text { façade } \\
\text { system }\end{array}$ & $\begin{array}{l}\text { Color limited, } \\
\text { system life is } \\
\text { equal to/greater } \\
\text { than component } \\
\text { life, may violate } \\
\text { local zon- } \\
\text { ing/housing } \\
\text { requirements }\end{array}$ & $\begin{array}{c}\text { Low energy } \\
\text { cost, limited } \\
\text { solar } \\
\text { availability, } \\
\text { long payback } \\
\text { for high } \\
\text { initial cost }\end{array}$ \\
\hline $\begin{array}{c}\text { GE } \\
\text { Brilliance } \\
\text { Roof } \\
\text { Integrated } \\
\text { System }\end{array}$ & $\begin{array}{l}\text { Pre-packag } \\
\text { ed roofing } \\
\text { system }\end{array}$ & $\begin{array}{l}\text { Highly, } \\
\text { allows } \\
\text { for direct } \\
\text { replacement } \\
\text { of roofing } \\
\text { material }\end{array}$ & $\begin{array}{l}80-100 \\
\text { kWh/ } \\
\text { month/ } \\
100 \text { sq. ft }\end{array}$ & $\begin{array}{l}\text { No specialist, } \\
\text { all in one } \\
\text { application, } \\
\text { self-contained, } \\
\text { works similar } \\
\text { to shingles } \\
\text { but larger, } \\
\text { light weight } \\
\text { 18 lbs/panel }\end{array}$ & $\begin{array}{l}\text { No special } \\
\text { maintenance, } \\
25 \text { year } \\
\text { warranty, } \\
\text { hail and } \\
\text { severe } \\
\text { weather } \\
\text { resistance }\end{array}$ & $\begin{array}{l}\text { Requires } \\
\text { modularity, } \\
\text { may not } \\
\text { cover } \\
\text { available } \\
\text { area } \\
\text { completely }\end{array}$ & $\begin{array}{c}\text { All } \\
\text { components } \\
\text { included, } \\
\text { may be } \\
\text { implemented } \\
\text { on facades }\end{array}$ & $\begin{array}{c}\text { Bluish-black } \\
\text { appearance, } 25 \\
\text { year warranty on } \\
\text { power output, } 5 \\
\text { years on work- } \\
\text { manship/ } \\
\text { components, } \\
\text { profile resem- } \\
\text { bles shingles }\end{array}$ & $\begin{array}{c}\text { May } \\
\text { substantially } \\
\text { effect energy } \\
\text { cost, price not } \\
\text { available, } \\
\text { payback } \\
\text { dependent } \\
\text { upon number } \\
\text { of panels, } \\
\text { rebates, } \\
\text { and output }\end{array}$ \\
\hline
\end{tabular}


Table 3. Necessary questions to answer to use the BIPV product comparison matrix.

\begin{tabular}{|c|c|}
\hline Category & Questions to ask \\
\hline Application & $\begin{array}{l}\text { 1) For what purpose is the system intended to operate towards? } \\
\text { 2) Is the system "off the shelf" or is it custom designed? } \\
\text { 3) Where on the residential project can system feasibly be installed? }\end{array}$ \\
\hline Suitability & $\begin{array}{l}\text { 1) Do the climate, location, and orientation of the system play a role in how effective it could be? } \\
\text { 2) Are related building components able to be replaced by these systems? }\end{array}$ \\
\hline Efficiency & $\begin{array}{l}\text { 1) What is the efficiency of the system being considered? } \\
\text { 2) What ways does this system/component increase the building efficiency? }\end{array}$ \\
\hline Constructability & $\begin{array}{l}\text { 1) Is there any installation difficulties? } \\
\text { 2) What type of laborer does it take to install them (specialists or common trades)? } \\
\text { 3) Does the unit require custom fabrication? } \\
\text { 4) How much prefabrication can be undertaken before installation? }\end{array}$ \\
\hline Maintenance & $\begin{array}{l}\text { 1) What level of maintenance is required to keep the system operational? } \\
\text { 2) When an item needs replaced how easy is it to be replaced, and does the entire system need to be replaced? }\end{array}$ \\
\hline Modularity & $\begin{array}{l}\text { 1) What are the modular attributes and properties? } \\
\text { 2) Does the modular attributes align with the physical home? } \\
\text { 3) Is the product able to be modified in-field or does it require custom manufacturing? }\end{array}$ \\
\hline Integration & $\begin{array}{l}\text { 1) How cohesive and adopted is the system to the existing home? } \\
\text { 2) Does the product have dual functions to replace any systems that must be removed? } \\
\text { 3) What aspects must be considered in the renovation for the system to be integrated successfully? }\end{array}$ \\
\hline Aesthetics & $\begin{array}{l}\text { 1) Is the product visually pleasing or is it obstructive? } \\
\text { 2) Does it meet local/national codes and zoning requirements? } \\
\text { 3) What are the aesthetic options for the product to choose from? }\end{array}$ \\
\hline Energy Cost & $\begin{array}{l}\text { 1) What is the local energy rate for the surrounding region? } \\
\text { 2) Does the cost of BIPV have a good comparison to the local rates? } \\
\text { 3) What is the payback per year, the payback period, lifecycle cost for the system? }\end{array}$ \\
\hline
\end{tabular}

Table 4. Attribute table with potential systems for comparative purposes with examples.

\begin{tabular}{|c|c|c|c|c|c|c|c|c|c|c|c|c|c|c|c|c|c|c|c|}
\hline \multirow[b]{2}{*}{ System } & \multicolumn{5}{|c|}{ Construction } & \multicolumn{4}{|c|}{ Weather } & \multicolumn{4}{|c|}{ Structural } & \multicolumn{3}{|c|}{ Enclosure } & \multirow[b]{2}{*}{ 푱 } & \multirow[b]{2}{*}{ 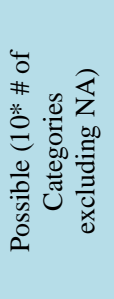 } & \multirow[b]{2}{*}{ 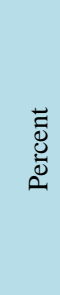 } \\
\hline & 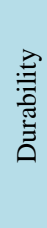 & 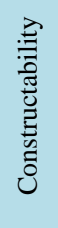 & 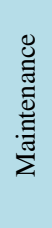 & 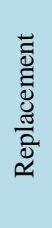 & 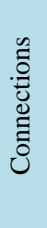 & 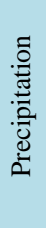 & 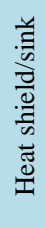 & 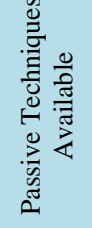 & 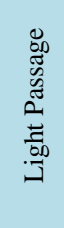 & 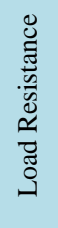 & 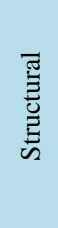 & 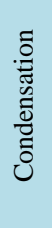 & 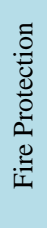 & $\begin{array}{l}\stackrel{D}{0} \\
\stackrel{D}{D}\end{array}$ & 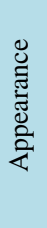 & 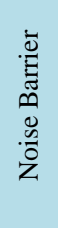 & & & \\
\hline Thin Film Glass & 8 & 10 & 10 & 8 & 7 & 8 & 6 & 5 & 10 & NA & 10 & 8 & 7 & 8 & 9 & 3 & 117 & 150 & $78 \%$ \\
\hline Wall Panel & 7 & 5 & 9 & 1 & 6 & 8 & 8 & 3 & NA & 10 & 1 & 5 & 8 & NA & 6 & 10 & 87 & 140 & $62 \%$ \\
\hline Roof System & 8 & 8 & 10 & 7 & 7 & 8 & 5 & 4 & NA & NA & 10 & 6 & 5 & NA & 8 & NA & 86 & 120 & $72 \%$ \\
\hline
\end{tabular}

- Durability — describes how well the system holds up to the environment and its potential impacts.

- Constructability - describes how easily can the system be constructed and/or installed by typical trade professionals.

- Maintenance-identifies the required and recommended maintenance for the system.

- Replacement-identifies what the replacement costs, availability of components, and difficulty of replacing the system are.

- Connections - states the level of difficulty of connecting the system components.

- Precipitation-describes the component/system the ability to resist penetration of precipitation and how it affects energy output.

- Heat Shield/Sink - describes the system/component ability to perform as a heat barrier or storage unit.

- Passive Techniques Available_-states if the system can be used as a light shelf, solar shade, heat storing mass, or other types of passive solar functions. 
- Light Passage—indicates system allowance for the passage of light needed for daylighting.

- Load Resistance-identifies system support capabilities of the system to resist surrounding loads imposed by the building.

- Structural —states the requirements of mounting systems to the structure.

- Condensation-indicates if there is a chance of condensation occurring on the system that may affect efficiency or damage the panel.

- Fire Protection - states the fire resistance of the system.

- Privacy - describes the provided separation from the outside environment.

- Appearance-describes the aesthetic value or perception of system.

- Noise Barrier-indicates the selected system / component ability to provide noise isolation from entering or exiting interior space.

These developed matrices can help in the decision-making process with regard to the selection and installation of BIPV. These tables allow an interested owner or designer to quantitatively rate a process and product they are considering. These tools further allow for a numerical comparison of multiple technologies that may be utilized. The first Matrix (Table 2) allows for a broad scope picture of the technologies, while the second matrix (Table 4) focuses more on specifics and the choice of products. It is important to note that the matrices are not limited to the values filled, but can be modified and customized with different technologies and products, as well as with new technology as it becomes available.

\section{Applications of BIPV to Residential Homes for Renovation}

To understand the potential for BIPV applications for residential renovation/retrofit, work needs to be done to ensure the adaptability of new construction ideas to the existing single-family homes. Despite the many similarities, there are differences between new and existing single family buildings. In general, existing buildings pose greater challenges for BIPV development. Existing residential buildings have their own unique challenges that require more in-depth attention for BIPV application. There are some essential variations in design and construction that cannot be accounted for during planning stage. Also the wide range of construction techniques, structure age, possibility of hazardous material use in some buildings, and historic relevance of certain homes make such renovations challenging.

As this study looked toward innovative concepts and provides a proof of concept that home renovators can refer to, the best method to look at BIPV applications is through case study research. For the preliminary case study, a single-family dwelling located in Boalsburg, PA was chosen as the pilot home (Figure 1). The home was built as part of a market-rate residential development where some of the homes were constructed using the standard practices and a few homes, including the case study home were certified as a "green home" under the NAHB National Green Building Standard rating system. The home is approximately 1500 square feet and has been constructed using green materials, components, and techniques, including energy-efficiency strategies necessary to reduce energy demand in the dwelling (allowing PV technology to be more viable). The 2-bedroom, 2-bathroom house was constructed and was on the real estate market for \$272,000 at the time of the study (2010). The estimated energy cost is $\$ 100 /$ month. The home is selling at a "standard" building cost, with the developer essentially giving the sustainable and green features away for free. The construction of the home includes R-12 insulated foundations, engineered lumber products, 2" × 6” R-19 insulated exterior walls, Energy Star windows, PEX water lines, high efficiency heat pumps and water heaters, low flow toilets, as well as R-50 and R-58 insulated ceilings.

For this case study, a series of analyzes were conducted to look at a range of behaviors. These analyzes looked at comparisons of a standard home vs. the energy efficiency "green home", a parametric analysis of implementing photovoltaic arrays under varying circumstances, an analysis of thin film PV technology on the siding of the home to produce a BIPV envelope system, and an analysis of reflective material and the BIPV surfaces that include environment modifications. The following sections detail each analysis.

\subsection{Analysis: Standard Construction vs. Base Case}

For the first analysis, the software program Energy 10 was utilized to compare a typical home with similar dimensions to that of the case study home. Initial data was entered in Energy 10 version 1.7, which did not include the ability to process PV properties in its calculations. The final model used Energy 10 version 1.8, which al- 


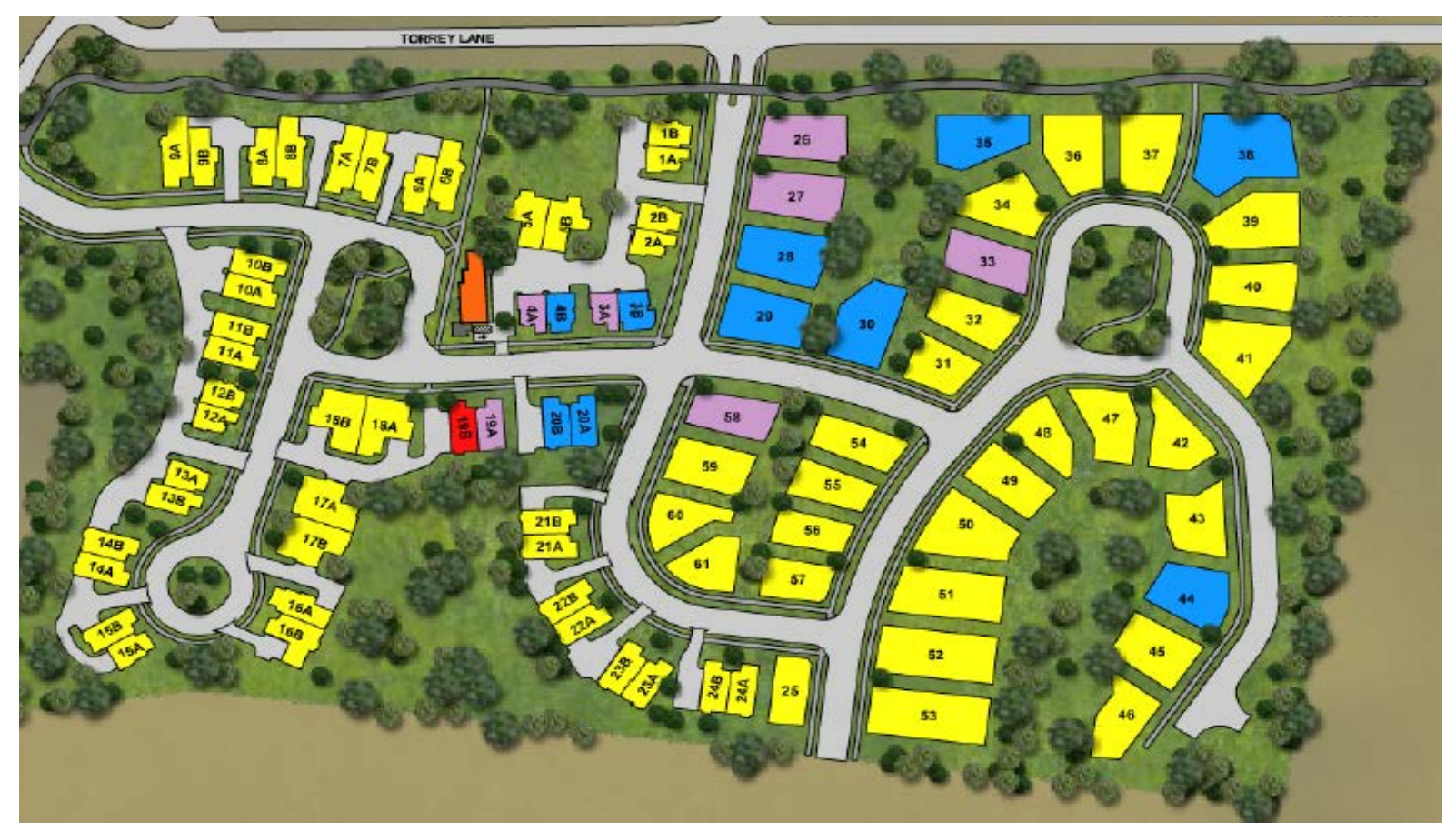

(a)

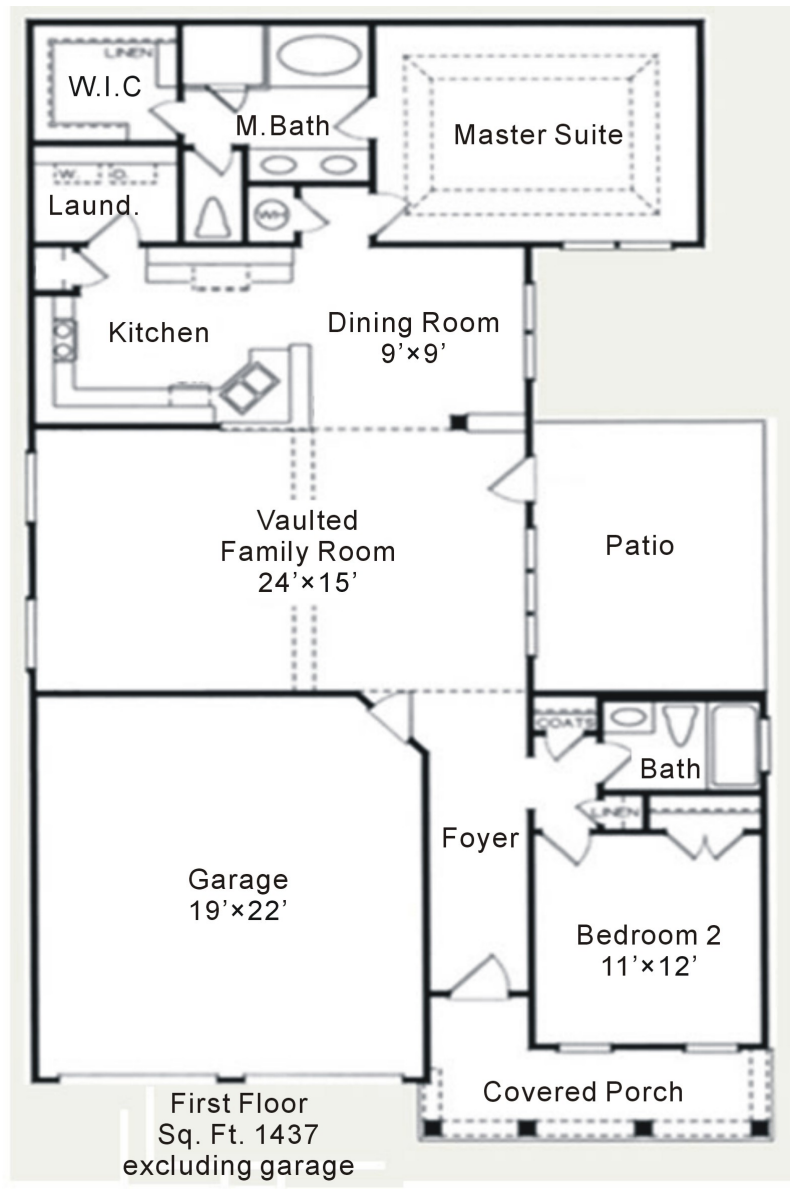

(b) 


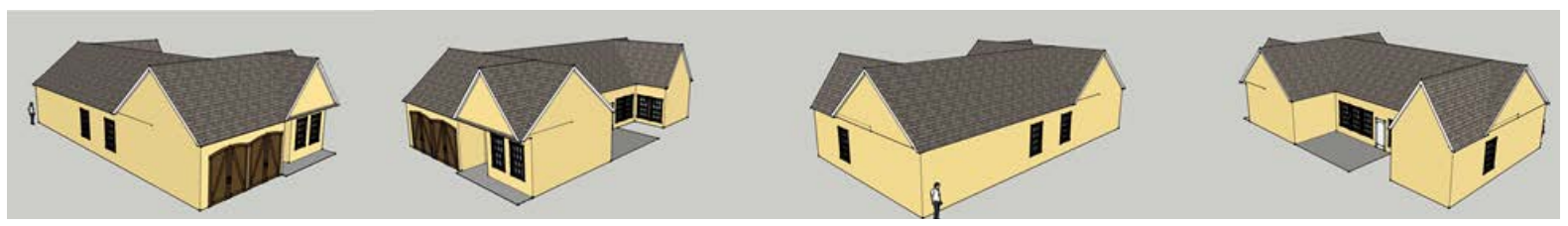

(c)

Figure 1. Case study home schematics. (a) Site location (Boalsburg, PA, USA); (b) Floor plan; (c) 3D perspectives.

lowed for PV integration. The weather file used for the analysis implemented Williamsport, PA data as it is the nearest city to the location of the home. Key differences in the summary are in Total Conduction UA, Average U-value, Wall Construction, Roof Construction, Window Construction, and Glazing name (type). These values represent the areas that have been modified in the home to create a green design. The results of such changes can be seen in Table 5 .

The operating parameters give comparative values between the two scenarios and show how a more "green" home typically operates. Lower set points in winter and higher in summer with setbacks and setups to compensate for occupancy of the home are typical. Also the use of an economizer for transition seasons, higher Energy Efficiency Ratio (EER), and use of day lighting are other means of offsetting energy use. Many of the changes in these values were direct results of changing the wall and roof type and the software's interpretation of providing a low energy case. For instance, the mechanical system was changed for a higher efficiency model with an economizer, air flow was reduced, and peak gains lowered by using more efficient products.

Using the value of $\$ 0.054 / \mathrm{kWh}$ and $\$ 2.47 / \mathrm{kW}$ as a standard provided by the software as defaults for energy cost to quantify the energy savings monetarily, the results of the analysis were calculated. Important to note is the reduction in energy use and cost in the green design home, as well as the reduction in energy demand during a 1-year period. Another interesting point to observe is the value of the home in terms of construction costs. According to Energy 10 a "standard" home of this type would cost about \$242,000 to build, while the more efficient, low energy home would cost about $\$ 258,000$, a $1.6 \%$ increase in price. This is also reflective of the sales price of the home at \$272,000 (based on the 2010 housing market for the area), giving the developer a 5.4\% profit margin over the cost of construction. The key however is in the lifecycle cost. The more sustainable home has a cost of about $\$ 293,000$, while the "standard” home has one that is $5.8 \%$ greater, $\$ 310,000$. This is important in the terms of sustainable homes in that a 1.6\% increase in cost for premium products and energy saving measures results in a $5.8 \%$ savings in life cycle costs.

\subsection{Analysis: Zeroing Out Energy Use Using South Facing Roofs}

A second analytical study was conducted to see if the home could be net-zeroed (producing as much electricity as is used in operating the home) in terms of energy use by implementing standard PV products on roofs as shown in Figure 2. "Zeroing Out" of a facility is the practice in which the facility uses no energy from the grid during a given interval, typically a year. The facility may need the grid for power during peak times, but overall, the self-generation of power by the facility is equal to or greater than that required for the facility. The PV products chosen are two PV systems from Atlantis Systems (MegaSlate and SunSlate)

(http://atlantisenergy.com/) and a BP Solar system (http://www.bp.com). The Atlantis products are more of an integrated system that resembles roof panels or shingles depending on the product selected. MegaSlate is larger and works well with a unitized system given its larger dimension. The SunSlate is more like a typical shingle in appearance with integrated PV products. The BP system, on the other hand, is a series of typical crystalline panels configured as an array.

Each product was selected for the study and the analyses were quantified in the output for each roof of the case study home or every month of the year. It is important to note that the products have the same simple payback, even though the MegaSlate is more efficient, this is offset by the higher initial cost. However, it was observed that a more typical array particular in the BP system has by far the best payback. It was also clear that a more typical PV system, such as the BP product, produces more electricity with the same area. Through that data collected, it was clear that the home could not "zero out" using the south roof surface alone, all systems modeled required the use of supplemental energy from the grid, albeit a small amount during certain months. The use of additional solar is necessary, whether by increasing the efficiency of the array, or through the use of addi- 
Table 5. Construction types differences for the analysis.

\begin{tabular}{ccc}
\hline & Standard & Green Home \\
\hline Total Conduction UA & 487.4 & 232.9 \\
Average U-value & 0.103 & 0.049 \\
Wall Construction & $2 \times 4$ Frame with $\mathrm{R}=12.6$ & $2 \times 6 \mathrm{Frame} \mathrm{with} \mathrm{R}=19$ \\
Roof Construction & $\mathrm{R}=29.4$ & $\mathrm{R}=60.2$ \\
Window Construction & 4060 wood $\mathrm{U}=0.47$ & Do60 Low-E Aluminum U $=0.31$ \\
Glazing name (type) & Double $\mathrm{U}=0.49$ & Double Low-E U = 0.26 with continuous dimming \\
Daylighting & No & Yes at 60F \\
Economizer & No &
\end{tabular}

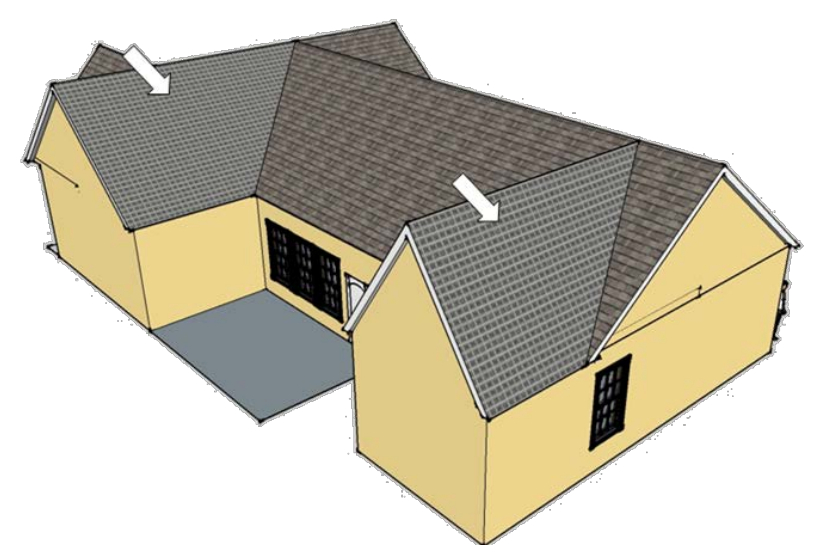

Figure 2. Location of material on the south facing roofs (note: the arrows indicate south facing roof with the PV panels attached).

tional surfaces. The next step was to consider using a BIPV system on the south and east facades due to the expanse of wall with few windows or openings in the case-study home.

\subsection{Analysis: Zeroing Out Energy Use Using Multiple Surfaces}

By adding BIPV system on the south and east facades, now multiple surfaces were able to be tested as one system. Efficiencies for various forms of PV systems are listed in Table 6 . These values range from 5\% to 50\%, which indicate that the full potential for the system in terms of operations has not yet been achieved. To understand total system efficiency, the surface in question needs to also be considered. Surface configuration adjusts the value of the typical product for its mounted orientation. Orientation deals with the magnetic direction of the surface. In other words, a south facing wall would have an orientation of 180 degrees, while an east wall would be 90 degrees and at west wall 270 degrees. In regards to surfaces, tilt angle is also needed. The tilt is the tilt angle of the surface. For a wall, the angle would be 90 degrees, while the angle for a surface parallel to the ground would be 0 degrees.

Using local information from the case study area and home, a numerical calculation performed using south facing arrays angled at a 30 degree tilt proved the choice to be optimal. Next it was determined that the south and east walls of the case study home had an average solar output per day per unit of $2.8 \mathrm{kWh} / \mathrm{m}^{2}$ day for vertical faces in the Williamsport area. The respective areas of the walls gave a material efficiency of 0.06 for amorphous silicon (PV a-Si) and respective orientation efficiency for each wall (0.67 for South wall and 0.53 for East wall) was determined. Plots of tilt and angle orientation for solar radiation are important in this decision process (Figure 3). Once these parameters were known, total energy generation could be determined. Additionally, the sun hours per day were important in that it allows for more energy production in an attempt to create a home that only relies on the grid to provide power during critical times, but allows the self-generation to compensate for the use during high self-generation periods when energy potentially could be placed back on the grid. With the addition of the BIPV on the south and east walls for reasons described earlier, a potential of 11,735 
Table 6. Standard efficiency ranges for different photovoltaics.

\begin{tabular}{cc}
\hline Technology & Efficiency Range \\
\hline SWH & $0.30-0.50$ \\
PV c-Si & $0.14-0.17$ \\
PV p-Si & $0.13-0.15$ \\
PV a-Si & $0.05-0.07$ \\
Passive & $0.20-0.50$ \\
Daylighting & $0.20-0.50$ \\
\hline
\end{tabular}

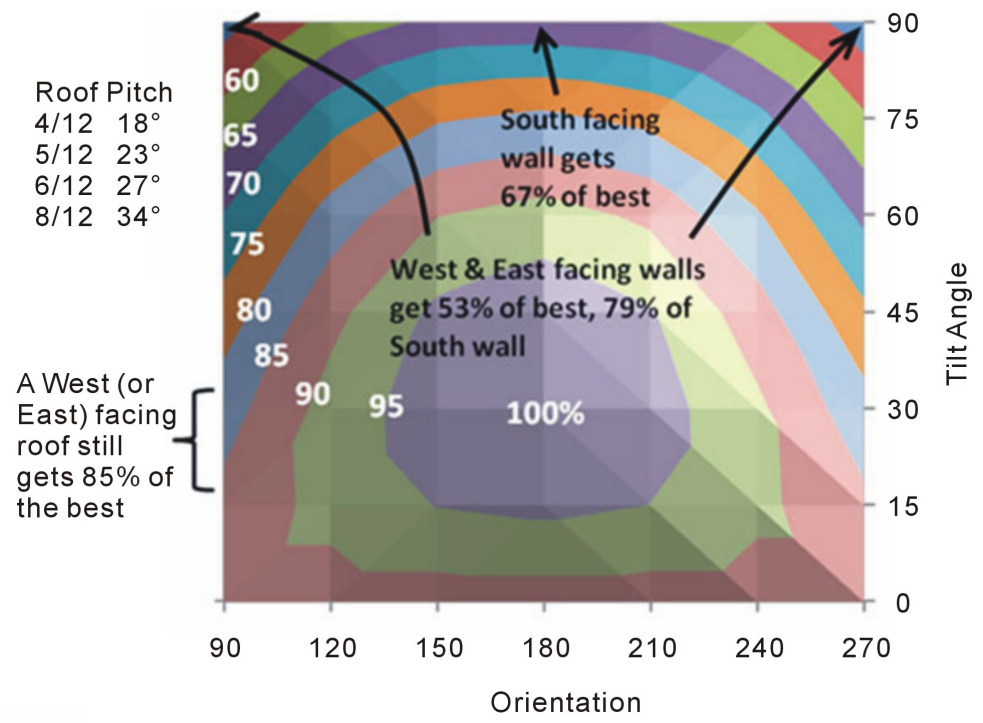

Figure 3. Effect of tilt and orientation on annual average solar radiation (for Harrisburg).

kWh of energy could be produced in the case study home.

\subsection{Enhancing BIPV Efficiency through Reflective Materials}

Next, this study involved the use of the landscaping elements in the patio area of the home to enhance BIPV efficiency. The idea was to advance the efficiency of applied PV systems that may be used on an existing home through the application of reflective materials. The hypothesis was that by using a reflective material for the patio, as well as adding features that enhance reflection of sunlight onto PV surfaces, the production of the BIPV located on the south facing patio wall will increase. To understand reflectivity and material applications, baselines needed to be established on common building materials often found in residential areas to provide a frame of reference for material selection. Table 7 provides a summary of materials, their reflectance, emmittances, solar reflection index and the age of the product as applicable. Values for solar reflectance range from 0 - 1 , with a value closer to 1 signifying a material that better reflects the energy of solar radiation (seen in Figure 4(b)). Solar angle graphs for a given area are needed to determine the location of the sun during the year in order to find its proper reflectivity (Figure 4(a)). In order to carry out renovations and retrofits, initially detailed research needs to be conducted to study the exact properties as each manufacturer can be different.

For improving the performance of PV \& BIPV systems, a variety of performance enhancements can be made to existing projects. These ideas, however, are not limited to renovation and retrofit but are applicable to new construction as well. There are 11 primary improvement focuses that may be observed as listed below. The remainder of this section summarizes these different techniques.

- Active Solar Tracking Reflection System

- Water Garden Landscaping

- Highly Reflective/ Light Colored Stone Landscaping 


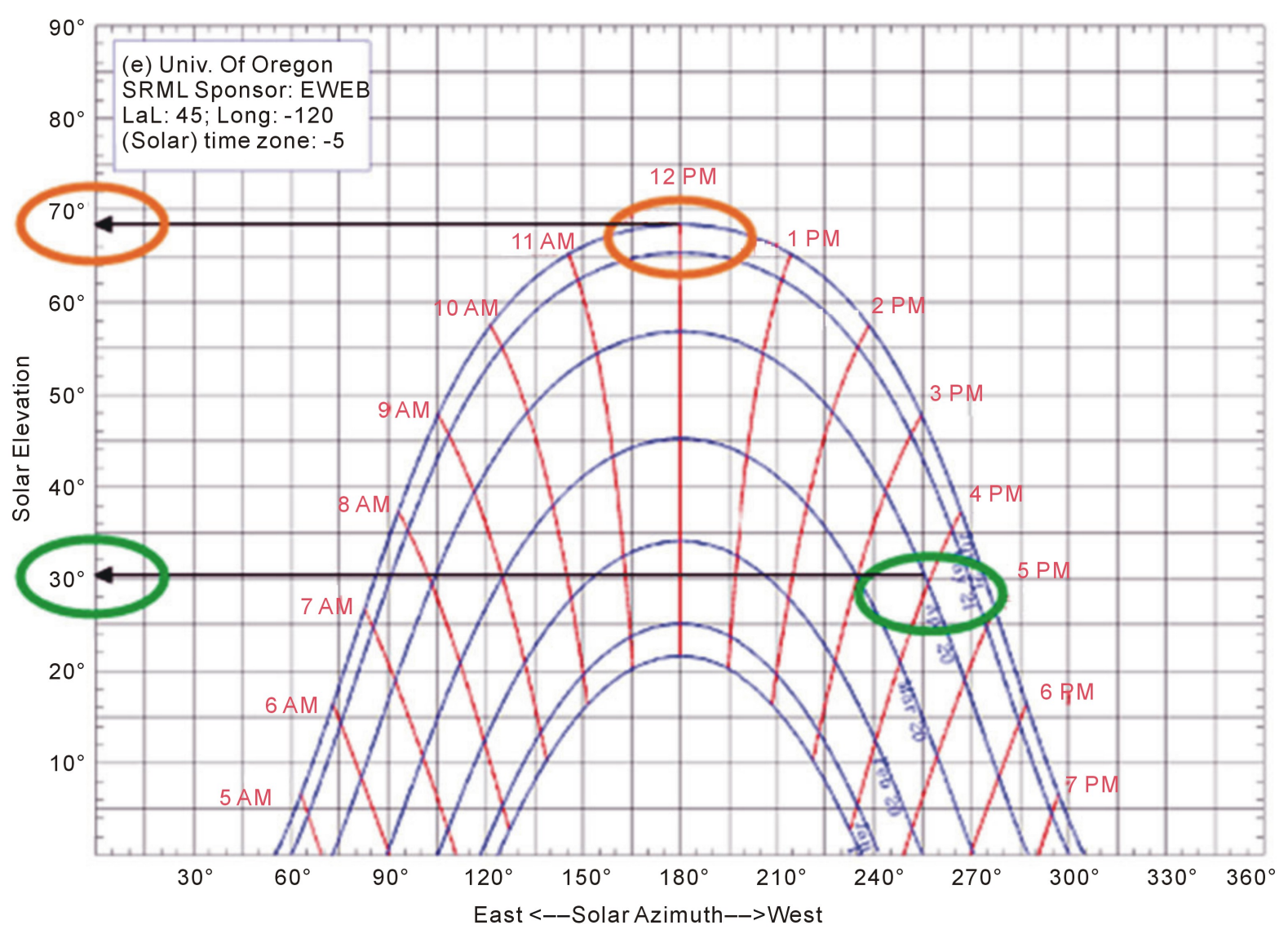

(a)

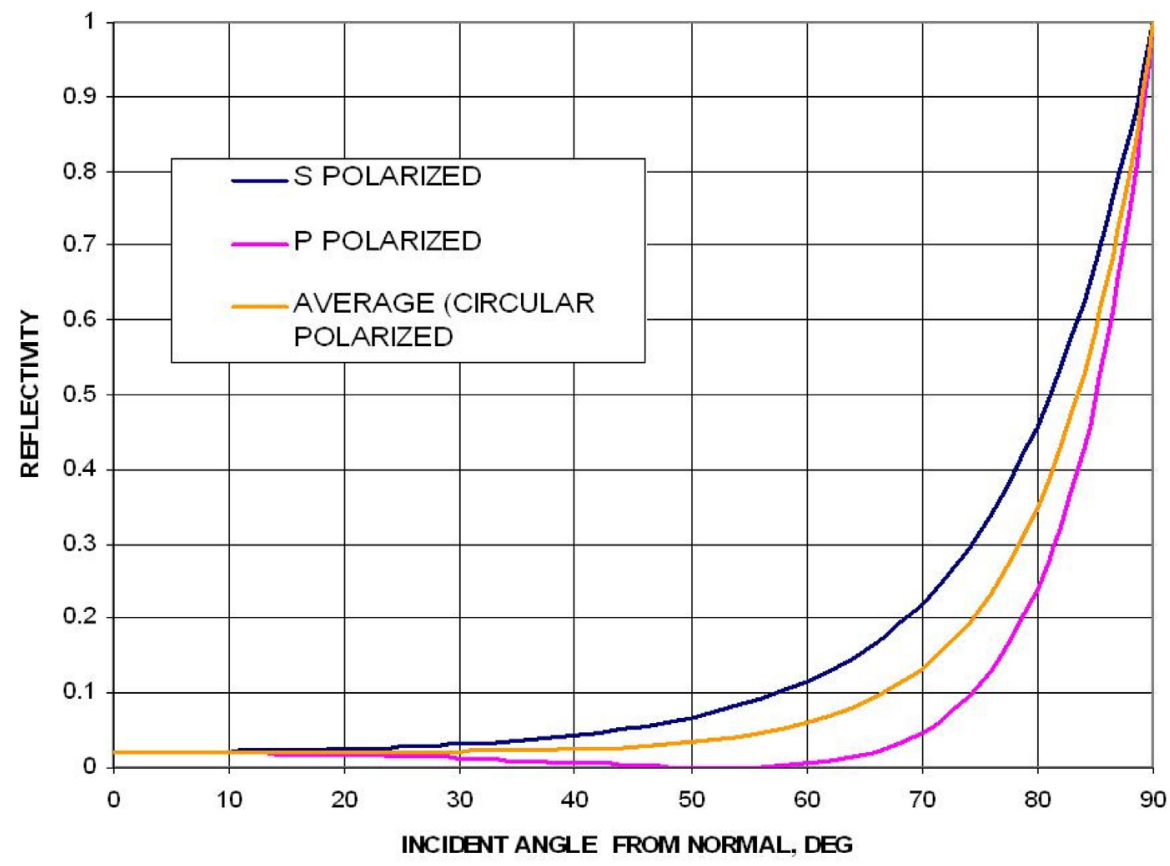

(b)

Figure 4. Representative solar charts needed for design. (a) Solar chart plot of elevation and azimuth; (b) Reflectivity plot of incident angle and reflectivity. 
Table 7. Reflectivity of common materials.

\begin{tabular}{ccccc}
\hline Material & Solar Reflectance & Emittance & Solar Reflectance Index & Age \\
\hline White Concrete & 0.7 & 0.9 & 86 & New \\
Gray Concrete & 0.35 & 0.9 & 35 & New \\
White Concrete & $0.68-0.77$ & 0.9 & 45 & weathered \\
Gray Concrete & $0.41-0.52$ & 0.9 & 19 & weathered \\
Average Concrete & 0.47 & 0.9 & - & New \\
High White Cement & 0.87 & - & - & New \\
Conifer Tree & $0.09-0.15$ & - & - & - \\
Deciduous Tree & $0.15-0.18$ & - & - & - \\
Bare Soil & 0.17 & - & - & - \\
Green Grass & 0.25 & - & - & - \\
Desert Sand & 0.4 & - & - & - \\
Fresh Snow & $0.8-0.9$ & - & - \\
Water & effective at low angles & & & - \\
\hline
\end{tabular}

- Reflective Decking Material

- Reflective/Mirrored Fencing

- Light Colored/Reflective Concrete

- Unaltered Snowfall in Winter

- BIPV Asphalt Shingles

- Window Integrated Thin Film PV

- BIPV Metal Roofing/Siding

- PV Integrated Deck Boards/Railing

Active solar tracking reflection systems use "solar reflectors" that actively track the sun to place additional radiation on areas not typically receiving sun during that time instance. While this system provides additional solar radiation, this system may be expensive and a less than pleasing aesthetic appearance. Water gardens could reflect radiation at times when the sun is low in the sky, such as early morning and late evening, providing increased radiation to the lower portion of the BIPV. This only affects the lower portion because of the limited width of the water garden and the low reflection angles. Sparse water vegetation could be included and the interior color of the system does not matter as the light is reflected off the surface of the water.

Light colored stone landscaping is already a highly popular way for residents to landscape their home. By using the light colored material, the opportunity to reflect radiation onto the façade is there. However, given the diffuse nature of the multiple surfaces the light would hit, the direct reflection is not obtainable. The stone landscaping would tend to reflect the light at all angles depending on the surface the light strikes. While not the most beneficial, it still provides the opportunity for gain on a system already in place. The use of a reflective or light colored material for decking would provide numerous benefits. First, since most of the radiation is directed away from the material, the temperature would not rise during peak sun hours. Also the radiation could be reflected onto the BIPV panels. This allows for more control of the reflection as well, since the deck can be sized and positioned in such a way to create the most benefit for the PV system. However, as is the case with reflective materials, glare is an issue. Also, the aesthetical value of a light colored or reflective deck versus a natural wood deck is an option to be weighed by the owner.

Fencing to separate properties is common, especially in development situations where structures are often located in close proximity. The ability to place a reflective or mirrored surface on the owner's side of the fence could prove beneficial in reflecting light onto a productive PV surface. The system would be passive as it would not track the sun, but would still be able to be calibrated to provide the most opportunity for increasing radiation on the intended surface. Again issues with glare and heat are present, but would be evaluated by the owner since it would only affect their home.

Light colored or reflective concrete can create large potential gains for the façade. The ability to reflect $40 \%$ $50 \%$ of the radiation onto a vertical surface drastically increases the production capabilities of the BIPV system. 
Another benefit to this system is concrete's characteristic as a heat sink mass, in that it can absorb and store the heat for release at a later time, such as in the late evening. Unaltered Snowfall in Winter works in much the same way as the water garden, concrete, and reflective decking does. Unaltered (Natural) snow provides very high reflectivity, most commonly seen as glare. The reflected radiation, while not able to be calibrated, could provide an excellent opportunity to reflect the horizontal radiation to the vertical façade. The smoother and flatter the snow, the better its chance at reflectivity without dispersion of radiation. The flat and smooth snow would act similarly to the light concrete, but with a higher level of reflectivity. The seasonal benefit of the increased performance of the PV system in winter may be a substantial gain since electricity demands may be greater due to heating loads.

Integration of thin film PV's onto or in asphalt shingles would provide a feasible way for current home owners to implement PV technology into their home using a fairly common product. The standard asphalt shingle is a well-known industry product that uses standard installation practices that are common to most contractors. Implementation of a BIPV material into or onto the shingle adds minimal weight and requires little or no additional training for contractors. Using semi-transparent thin film PV's in windows can be another application. This is a common BIPV application for curtain wall applications mostly in commercial buildings. However, expanding that market into single, operable windows could benefit the existing housing market. Using the same manufacturing methods, a semi-transparent thin film could be implemented into the air space in double or triple pane glass.

BIPV Metal Roofing/Siding can be achieved through thin film laminate PV's, such as Unisolar products (www.uni-solar.com), where a layer of PV can be attached directly to the surface of metal standing seam roofing. This has already been documented in the NAHB [14] study on homes. Products like this can be added later or during the manufacturing process, depending on the situation. PV Integrated Deck Boards/Railing advances reflective decking material beyond material type and color; this is achieved by installing a thin film PV system onto the decking material itself as a way to increase the overall area of BIPV. The $0^{\circ}$ tilt is much more efficient than using the $90^{\circ}$ tilt of a façade at producing energy, given the amount of $\mathrm{kWh} / \mathrm{m}^{2} /$ day that fall on the surface. Integration into the decking would require some type of protection, most likely a high strength polycarbonate or other scratch resistant topping material to avoid damage to the PV system. The aesthetical appearance of the system is again a consideration for the owner and the issue of the darker color deck, which would tend to heat up during the day, could potentially lead to rendering it unusable at times.

Applying these notions to the case study home, we can make several observations. First, the patio surface is currently light colored concrete, which has a reflectivity between 0.41 and 0.52 . The patio area is approximately $16.72 \mathrm{~m}^{2}\left(180 \mathrm{ft}^{2}\right)$. Using the reflectivity as a percent reflectance (in this case $41 \%$, the low value) the sun hours value for 0 degree tilt $\left(3.8 \mathrm{kWh} / \mathrm{m}^{2} /\right.$ day from previous charts and work) would yield approximately 1.59 $\mathrm{kWh} / \mathrm{m}^{2} /$ day as a reflected value. This amount of extra energy would then be falling onto the wall surface, thus increasing the sun hours value from $2.5 \mathrm{kWh} / \mathrm{m}^{2} /$ day to $4.09 \mathrm{kWh} / \mathrm{m}^{2} /$ day at certain locations. If the material is changed to white concrete, the low reflectance value would be 0.68 and would result in a $2.54 \mathrm{kWh} / \mathrm{m}^{2} /$ day increase. It is important to note that no inefficiencies have been addressed and would be necessary for detailed evaluation. These inefficiencies would prevent the sun hours from reaching predicted optimal levels and include imperfections in the surface of the material, dirt or dust, and aging of the material. However, the substantial benefit can be seen in the reflectability of the materials. Additional ideas include using water, which has higher reflectivity at high incident angles from normal, which in cases over 80 degrees incident angle from normal, are similar to or greater than concrete. This would increase the solar radiation during the early and late times of solar production in the day, thus allowing for power generation at peak times of use by the occupants (morning/evening). Another material studied was fresh snow. If the snow is not removed from the patio, reflectance values can jump as high as 0.9 , or twice the value of normal concrete.

Taking these multiple ideas on ways to improve the solar production of the BIPV or just PV in general through reflective materials, a composite implementation plan could be achieved. Several of the ideas revolved around reflecting or directing additional light onto a surface while others are passive and can be incorporated into other building components. Examples of active suggestions are presented in Figure 5.

The benefits of reflecting additional radiation onto a surface can be substantial enough to create large gains in the solar radiation falling on a specified face, depending on how the conditions are. Use of the charts allows for any date and time to be evaluated for results. It is also important to note the lack of inefficiencies in these exercises, and the need to account for such inefficiencies as deterioration, aging, and dirt among other factors. 

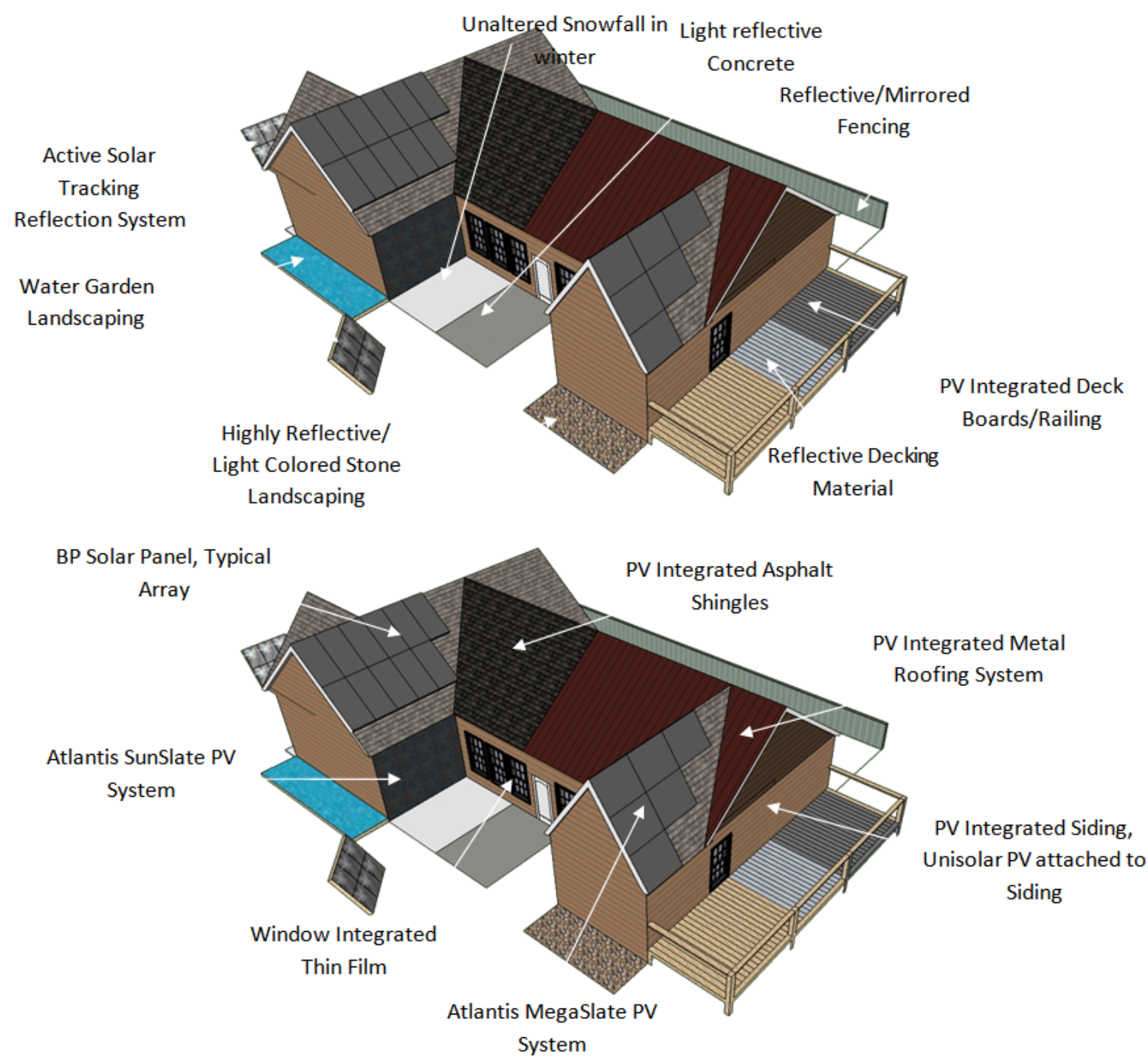

Figure 5. Potential areas for BIPV integration with material enhancements.

\section{Discussion}

With respect to incorporation of BIPV on existing housing stock, site factors become less manipulative and more of a fixed obstacle to overcome. Considerations on building orientation, site layout, vegetation location and types, weather patterns, adjacent buildings, and size of renovation all play important roles in deciding on the appropriateness of BIPV. Because typical renovation of existing housing stock is primarily related to external building elements degrading by natural exposure and renovations occur after design, the full integration of BIPV becomes more difficult. Existing roof penetrations such as chimneys, vent stacks, and fans pose additional issues for the practicality of BIPV. Such components are difficult to relocate in order to avoid shadows on the PV array and/or odd layouts of BIPV components. Besides future gains in energy savings, the incorporation of PV systems may also need to appeal to the customer's values, economics, prestige, and positive image to the property and owner. Accordingly, potential manufacturers of BIPV must create a rugged, easy to install, aesthetically pleasing, sustainable, and low maintenance system that easily replaces an exterior weather proofing material [16]. An important note is that some PV systems are warranted with an estimated life-time of 20 - 30 years, on the same order as for typical construction materials. Without such attributes, the BIPV system will not be competitive in the market and will only be utilized by those early in the innovation curve.

To enhance the productivity of BIPV, it is also necessary to study the surroundings in proximity to the system. 
The efficiency of non-south facing BIPV can be an issue. Typical landscaping of residential buildings includes features that may affect the efficiency as well. Ideas such as the use of reflective or lightly colored decking/patio material in the rear of the home to help reflect solar radiation onto panels in the rear of the home can significantly enhance energy production. Use of mirrors or strategically placed reflective landscape can also accomplish this task. Residential landscaping frequently includes "foundation planting", vegetation around the base of the home, the shadow cast by this vegetation may prove harmful to the BIPV system efficiency. However, by carefully locating planting areas and using different types of vegetation it may be possible to increase the efficiency of the system.

Possible ideas for further expansion of BIPV technologies for implementation lie in vertical modules. These could include items like: siding, windows through thin film installation between glass layers, shutters, shading devices, architectural features such as awnings, landscaping features such as trellises or fencing, and deck and railing material.

\section{Conclusions}

This preliminary study has presented a state-of-the-art review of the literature and products on BIPV in relation to general industry domain and specific to residential construction. Concepts were presented here that home owners and contractors can use to add enhancement in selecting BIPV for single-family dwellings while maximizing their efficiency. These systems provide home owners with the ability to utilize a sustainable and power producing material as a renovation or replacement building component. The ability to provide a simple installation for common component replacement, such as siding or decking, could prove to be a valuable to not just the owner but to the community and more broadly to sustainability initiatives.

Considering the current state-of-the-art technology for BIPV roofing systems, with some modification/revisions, the existing technologies may be converted to vertical BIPV that would meet owner desired criterion developed through the matrices established. For such applications, it should be kept in mind that existing residential buildings pose more constraints compared to new construction. Serious consideration into the surroundings is also important to the success of BIPV applied to vertical surfaces. Furthermore, determining layouts and materials that improve the system's efficiency should be a main consideration. Finally, the economics of a vertical BIPV system should be evaluated in detail. For some potential clients, if enough power can be harnessed by a roof integrated BIPV system or applied PV system, they may not consider a vertical system given the potential inefficiencies. Development of benefits over roof mounted or integrated systems will help advance the use of vertical systems.

Reflecting upon the results, it is clear that further research is necessary in many areas that have been reviewed. The first area is that of material reflectivity and increasing solar insolation using both common and uncommon landscaping techniques. Using controlled experiments, the effect of increased solar insolation due to reflectance can be evaluated. Follow-up research could further confirm and validate some of the concepts presented that the increase in insolation could drastically improve the BIPV or PV system enough to merit the use of material for reflectivity. Following in line with this, further consideration on the impacts studied on the test home in Boalsburg, Pa should also be studied in different locations to compare the effects of BIPV with various climates. The second area of continual research should look further into incorporating BIPV into the existing housing stock, as many materials presented and reviewed were intended for use in new construction. By advancing these technologies, the base of potential customers could drastically increase given the much larger number of existing homes.

\section{Acknowledgements}

The authors gratefully acknowledge the support of Sunrise Homes for their support in providing the information and documentation for the case study home used in this report. Additionally, the financial support of the Raymond A. Bowers Foundation for this study is gratefully acknowledged.

\section{References}

[1] James, T., Goodrich, A., Woodhouse, M., Margolis, R. and Ong, S. (2011) Building-Integrated Photovoltaics (BIPV) in the Residential Sector: An Analysis of Installed Rooftop System Prices. National Renewable Energy Laboratory (NREL), Golden, CO. http://dx.doi.org/10.2172/1029857 
[2] Strong, S. and Scheller, W.G. (1994). The Solar Electric House-Energy for the Environmentally Responsive Energy-Independent Home. Sustainability Press, New York, NY.

[3] Sick, F. and Erge, T. (1996) Photovoltaics in Buildings-A Design Handbook for Architects and Engineers. International Energy Agency (IEA), Paris, France.

[4] Solar Energy International (2004) Photovoltaics: Design and Installation Manual. New Society Publisher, Gabriola Island, BC.

[5] Matthews, H.S., Cicas, G. and Aguirre, J. (2004) Economic and Environmental Evaluation of Residential Fixed Solar Photovoltaic Systems in the United States. Journal of Infrastructure System, 10, 105-110. http://dx.doi.org/10.1061/(ASCE)1076-0342(2004)10:3(105)

[6] Prasad, D., Snow, M. and Watt, M. (2005) Best Practice Guidelines for Solar Power Building Projects in Australia. Renewable Energy Industry Development (REID 7) Program, The University of New South Wales (UNSW).

[7] Farrigton, R. (1993) Building Integrated Photovoltaics. National Renewable Energy Laboratory (NREL), Golden, CO.

[8] Strong, S. (2009) Building Integrated Photovoltaics (BIPV). Whole Building Design Guide (WBDG), National Institute of Building Sciences, 1-6. http://www.wbdg.org/resources/bipv.php

[9] Eiffert, P. and Kiss, G.J. (2000) Building-Integrated Photovoltaic Design for Commercial and Institutional Structures A Sourcebook for Architects. National Renewable Energy Laboratory (NREL), Report BERL/BK-520-25272, Oakridge, TN.

[10] Jelle, B.P., Breivik, C. and Rokenes, H.D. (2012) Building Integrated Photovoltaic Products: A State-of-the-Art Review and Future Research Opportunities. Solar Energy Materials \& Solar Cells, 100, 69-96. http://dx.doi.org/10.1016/j.solmat.2011.12.016

[11] Malkawi, A.M., Yi, Y.K. and Lewis, G. (2005) Integrated Evaluation of a Photovoltaic Installation. Journal of Architectural Engineering, 11, 131-138. http://dx.doi.org/10.1061/(ASCE)1076-0431(2005)11:4(131)

[12] Benemann, J., Chehab, O. and Schaar-Gabriel, E. (2001) Building-Integrated PV Modules. Journal of Solar Energy Materials and Solar Cells, 67, 345-354. http://dx.doi.org/10.1016/S0927-0248(00)00302-0

[13] Baechler, M.C., Gilbride, T., Ruiz, K., Steward, H. and Love, P.M. (2007) High-Performance Home Technologies: Solar Thermal \& Photovoltaic Systems. Pacific Northwest National Laboratory, Report NERL/TP-550-41085, PNNL-16362. June 2007, Springfield, VA.

[14] NAHB Research Center (1997) Advancing Housing Technology Program—Building Integrated Photovoltaic Project in the 21st Century Townhouses. National Association of Home Builders (NAHB) Research Center, Upper Marlboro, MA.

[15] Riffert, S.B., Wilson, R. and Omar, S. (2000) BIPV Design Study for Renewable Energy Center and Eco-Energy House, Report ETSU S/P2/00325/REP/1. School of the Built Environment, The University of Nottingham, Nottingham, UK.

[16] Elzinga, D. (2008) Urban BIPV in the New Residential Construction Industry. International Energy Agency (IEA) Photovoltaic Power Systems Program, Report IEA-PVPS-T10-03, Paris, France.

[17] Memari, A.M., Iulo, L.D. and Stultz, C.R. (2010) Building Integrated Photovoltaic Systems for Single Family Dwellings-Efficiency and Innovation Concepts. Report to the Raymond Bowers Foundation, Penn State University University Park, PA.

[18] Sinapis, K. and van den Donker, M. (2013) BIPV Report 2013: State of the Art in Building Integrated Photovoltaics, Solar Energy Application Centre (SEAC), Netherlands. http://www.seac.cc/fileadmin/seac/user/doc/SEAC_BIPV_Report_2013.pdf.

[19] Wortman, D. and Echo-Hawk, L. (1999) Photovoltaic and Solar-Thermal Technologies in Residential Building Codes. Technical Report NREL/TP-520-26579, 1999, National Renewable Energy Laboratory, Golden, CO.

[20] Santos, I.P. and Rüther, R. (2012). The Potential of Building-Integrated (BIPV) and Building-Applied Photovoltaics (BAPV) in Single-Family, Urban Residences at Low Latitudes in Brazil. Energy and Buildings, 50, 290-297. http://dx.doi.org/10.1016/j.enbuild.2012.03.052.

[21] Gosh, S.D. and Modeja, R. (2006) Effect of Envelope on Residential Cooling Load Coupled with Use of Solar/Photovoltaic Panels. Journal of Energy Engineering, 132, 74-80. http://dx.doi.org/10.1061/(ASCE)0733-9402(2006)132:2(74)

[22] Perfetto, J. (2013) Building Integrated Photovoltaic Systems: Technical and Architectural Issues. (n.d.). Solar Design Alternative Energy Systems, Solardesign Arch. Perfetto, Italy. http://www.solardesign.it

[23] Cole, R.J., Crowley, P., Davidson, B. and McDonald, I. (2004) Mainstreaming Building-Integrated Photovoltaics in Canada. UBC School of Architecture, Royal Architectural Institute of Canada, Natural Resources Canada. 
[24] Henson, J. (2005) Integrating BIPV: How the Market for Building Integrated Photovoltaics Is Being Created in the USA. Refocus, 6, 28-30. http://dx.doi.org/10.1016/S1471-0846(05)70396-6

[25] Koebel, C.T., Papadakis, M., Hudson, E. and Cavell, M. (2004) The Diffusion of Innovation in the Residential Building Industry. US Dept. of Housing and Urban Development, Office of Policy Development and Research, Washington DC.

[26] Fong, K.F. and Lee, C.K. (2012) Towards Net Zero Energy Design for Low-Rise Residential Buildings in Subtropical Hong Kong. Applied Energy, 93, 686-694. http://dx.doi.org/10.1016/j.apenergy.2012.01.006. 